Comunicación

\title{
EFECTO DE DIFERENTES TRATAMIENTOS DE SUELOS SOBRE LA PRODUCTIVIDAD Y CALIDAD DE LOS CULTIVOS DE LECHUGA Y TOMATE EN INVERNADERO
}

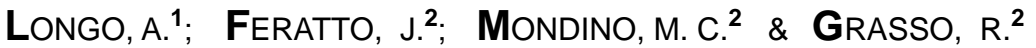

\begin{abstract}
RESUMEN
En los cultivos bajo cubierta se hace un uso muy intensivo del suelo, lo que produce "fatiga de suelo”. La utilización de bromuro de metilo, presenta excelentes resultados en el control de patógenos de suelo, pero afecta la capa de ozono. El objetivo del trabajo fue evaluar la efectividad de diferentes tratamientos de suelo, relacionándola con la productividad y calidad de lechuga y tomate en invernadero.

El trabajo se realizó en Rosario. Los tratamientos fueron: vapor, solarización, dazomet, bromuro de metilo y un testigo sin tratar. Las variables analizadas fueron: rendimiento y calidad. Se realizaron cinco tratamientos con cuatro repeticiones, se evaluaron por análisis de variancia y se determinó diferencias según Tukey.

Luego de dos años de realizadas las aplicaciones, se destacan por su mayor efectividad sobre los cultivos (rendimiento y calidad), los tratamientos con Bromuro de metilo, Dazomet y Vapor.

Palabras claves: fatiga de suelo, enfermedades, tratamientos de suelo.
\end{abstract}

\section{SUMMARY}

Effect of different soil treatments on the productivity and quality of lettuce and tomato greenhouse crops

Soil use in greenhouse crops is very intensive, and can produce "soil degradation". The use of methyl bromide, presents excellent results in controlling soil pathogens, but it affects the ozone layer. The objective of this work was to evaluate the effectiveness of alternatives to bromide, on the greenhouse lettuce and tomato productivity, and quality.

The trial was carried out in Rosario,. Treatments were: steam, solarization, dazomet, methyl bromide and check. The analyzed variables were: yield and quality. Five treatments with four repetitions were evaluated by analysis of variance and differences were calculated with Tukey. Two years after the treatments, Methyl Bromide, Dazomet and Vapan showed more effectiveness on treated crops (more yield and quality).

Key words: soil degradation, diseases, soil treatments.

1.- Facultad de Ciencias Agrarias. Universidad Nacional de Rosario AER INTA Arroyo Seco. Agente de proyecto Cambio Rural. Arroyo Seco, provincia de Santa Fe. E-mail: alelongo@arnet.com.ar

2.- Facultad de Ciencias Agrarias. Universidad Nacional de Rosario. C.C. 14, (2123) Zavalla, provincia de Santa Fe. E-mail: ferratto@satlink.com

Manuscrito recibido el 22 de enero de 2002 y aceptado para su publicación el 27 de marzo de 2002. 